\title{
Pendampingan Pelaku Usaha Melalui Dempond Pembenihan Ikan Lele (Clarias gariepinus) dan Pemasaran di Kecamatan Kalirejo, Kabupaten Lampung Tengah, Provinsi Lampung
}

\author{
[Assistance for Business Actors Through Demonstration Pond (Dempond) of \\ Catfish (Clarias gariepinus) Hatchery Business Breeding and Marketing in \\ Kalirejo Sub-District, Lampung Province]
}

\author{
Bayu Prastiyo ${ }^{1}$, Yuke Eliyani $^{1}$, Asnawi $^{1}$, Basuki ${ }^{2}$ \\ ${ }^{1}$ Program Studi Penyuluhan Perikanan, Politeknik Ahli Usaha Perikanan \\ JI. Cikaret No. 2 Bogor Selatan, Kota Bogor \\ ${ }^{2}$ Balai Riset Perikanan Perairan Umum dan Penyuluhan Perikanan (BRPPUPP) Palembang \\ JI. Gub H Bastari No.8, Jakabaring, Kecamatan Seberang Ulu I, Kota Palembang, Sumatera Selatan
}

Diterima: 8 Oktober 2021; Disetujui: 31 Desember 2021

\begin{abstract}
Abstrak
Penelitian dilaksanakan di Kelompok Taruna Mina Karya, Kecamatan Kalirejo Provinsi Lampung, mulai tanggal 8 Maret sampai 5 Juni 2021.Tujuan kegiatan ini meningkatkan hasil produksi benih melalui pemijahan buatan pada pembenihan ikan lele, serta meningkatkan kemampuan pelaku usaha untuk memperluas wilayah pemasaran benih ikan lele melalui media internet. Aksi penyuluhan adalah dempond pembenihan ikan lele secara buatan serta proses pemasaran daring. Hasil pelaksanaan kegiatan penyuluhan perikanan yaitu : (a) dempond pemijahan buatan ikan lele menggunakan perbandingan dua ekor induk jantan dan satu ekor induk betina dengan hasil produksi benih yang diperoleh 67.740 ekor. Proses dempond pembenihan ikan lele secara buatan terbukti dapat meningkatkan hasil produksi dilihat dari perbandingan hasil produksi dengan metode pemijahan alami yang menggunakan dua induk betina hanya menghasilkan 85.000 ekor. (b) pemasaran daring yang dilakukan telah menjangkau wilayah pasar yang lebih luas sampai keluar Provinsi lampung antara lain yaitu wilayah Tangerang dan Bogor. Pemasaran melalui media internet dapat meningkatkan harga jual, di mana yang sebelumnya hanya mencapai Rp.90 - Rp.100 per ekor pada ukuran benih 5-7 cm setelah melakukan pemasaran melalui internet harga jual benih menjadi Rp.150 - Rp.170 per ekor. Aspek pengetahuan mengalami peningkatan rata-rata $43 \%$, aspek sikap menunjukkan perubahan dari kategori tidak setuju menjadi kategori setuju dengan nilai mutlak $90 \%$. Aspek keterampilan berubah dari kategori tidak terampil rata-rata menjadi cukup terampil.
\end{abstract}

Kata kunci: ikan lele; pemasaran; pembenihan; penyuluhan; produksi

\section{Abstract}

The research was carried out at the Mina KaryaTaruna Group, Kalirejo District, Lampung Province, from March 8 to June 5 2021. The purpose of this activity was to increase production through artificial spawning in catfish hatcheries, as well as to increase the ability of business actors to expand the marketing area of catfish seeds through internet media. The extension action is demonstration of artificial catfish hatchery and online marketing process. The results of the implementation of fishery extension activities are: (a) artificial spawning demonstrations of catfish using a ratio of two male and one female broodstock with 67,740 seeds obtained. The artificial catfish hatchery dempond process was proven to increase production yields seen from the comparison of production results with natural spawning methods using two female broodstock only produced 85,000 seeds. (b) the online marketing carried out has reached a wider market area outside the Lampung Province, including the Tangerang and Bogor areas. Marketing through internet media can increase the selling price, which previously only reached Rp.90 - Rp.100 per head at $5-7 \mathrm{~cm}$ seed. The knowledge aspect increased by an average of $43 \%$, the attitude aspect 
showed a change from the disagree category to the agree category with an absolute value of $90 \%$. The skill aspect changes from the average unskilled category to moderately skilled.

Keywords: catfish; marketing; breeding; extension; production

\section{Penulis Korespondensi}

Yuke Eliyani | yukeeliyani@yahoo.co.id

\section{PENDAHULUAN}

Kecamatan Kalirejo mempunyai luas $104,32 \mathrm{~km}^{2}$ dengan pemanfaatan wilayah antara lain seluas 816 ha digunakan untuk pemukiman penduduk dan bangunan gedung, 1.023 ha untuk pertanian terutama tanaman padi, 8.065 ha untuk perkebunan terutama kelapa sawit, karet, singkong, dan kakao, 132 ha untuk kolam atau empang yang dimanfaatkan sebagai wadah usaha bidang perikanan, serta 396 ha untuk pemanfaatan lahan lainnya yaitu pemakaman, lapangan umum dan akses jalan. Kecamatan Kalirejo terbagi menjadi 17 Kelurahan, dengan jumlah penduduk 69.193 jiwa (BPS 2019), sebanyak 0,27\% atau 193 jiwa dari total Jumlah Penduduk, bermata pencaharian sebagai pembudidaya ikan yang telah diakui oleh Dinas Perikanan Kabupaten Lampung Tengah (BPS 2019). Hasil identifikasi permasalahan yang ditemukan di lapangan diantaranya teknologi pemijahan dan pemeliharaan yang masih tradisional yang berdampak pada hasil produksi, di mana Survival Rate masih rendah, serta harga jual rendah dikare- nakan tidak memiliki pasar untuk hasil produksinya (Prastiyo 2021).

Proses saluran pemasaran yang terjadi di Kecamatan Kalirejo pada pelaku usaha pembenihan ikan lele secara umum terdapat empat saluran pemasaran, yang melibatkan empat lembaga pemasaran yaitu pelaku budidaya ikan sebagai produsen, pengepul ikan wilayah kecamatan, pedagang pengecer dan konsumen. Namun dari empat saluran yang ada berdasarkan pernyataan pelaku usaha, penjualan benih ikan masih dikatakan susah dilakukan karena kurangnya pasar pada pelaku usaha pembenihan serta banyak pengepul ikan yang memainkan harga benih sampai berkisar Rp.60 pada ukuran benih $7 \mathrm{~cm}$ sedangkan harga normal pada pelaku pembesaran ikan mencapai Rp 100-120 (Prastiyo 2021). Tujuan penelitian ini adalah meningkatkan hasil produksi dengan cara pemijahan buatan pada pembenihan ikan lele, meningkatkan kemampuan pelaku usaha pembenihan lele untuk memperluas wilayah pemasaran benih ikan lele melalui media internet serta meningkatkan keuntungan pelaku usaha pembenihan ikan lele 
dengan cara meningkatkan harga jual benih ikan lele.

\section{BAHAN DAN METODE}

Penelitian dilaksanakan mulai tanggal 8 Maret sampai dengan tanggal 5 Juni 2021 yang berlokasi di kolam usaha milik Bapak Timbul, dengan sasaran penyuluhan yaitu anggota $\mathrm{Ke}$ lompok Taruna Mina Karya, Kecamatan Kalirejo Kabupaten Lampung Tengah, Provinsi Lampung. Tempat yang digunakan untuk melakukan dempond yaitu kolam usaha pembenihan ikan lele dari salah satu pelaku usaha yang berlokasi di Desa Sukosari Kecamatan Kalirejo Kabupaten Lampung Tengah tepatnya pada kolam Bapak Timbul. Materi yang diberikan kepada sasaran penyuluhan dalam segmen pembenihan ikan lele yaitu tentang penerapan teknologi pembenihan ikan lele secara buatan dan sistem pemasaran daring.

Metode penyuluhan yang digunakan adalah demonstrasi percontohan usaha yang merupakan metode penyuluhan melalui pendekatan individu dan kelompok pada pelaku usaha. Media pemaparan materi yang digunakan dalam kegiatan penyuluhan yaitu media cetak berupa folder/leaflet. Sasaran penyuluhan adalah pelaku usaha perikanan pada kelompok Taruna Mina Karya yang ada di Kecamatan Kalirejo tepatnya di Desa Sukosari yang mem- butuhkan binaan dan informasi teknologi pada usaha pembenihan ikan lele. Sasaran kegiatan penyuluhan berjumlah 12 orang pelaku usaha pembenihan ikan lele.

\section{Kegiatan Penyuluhan}

Dempond Pembenihan Ikan Lele Secara Buatan

Pemeliharaan induk ikan lele dilakukan pada kolam terpisah berdasarkan jenis kelamin induk. Pemeliharaan induk sebanyak 45 ekor menggunakan empat kolam milik Bapak Timbul yang berukuran 1,5 $\mathrm{m} \times 3 \mathrm{~m}$ dengan kedalaman air kurang lebih $80 \mathrm{~cm}$. Pakan yang digunakan untuk proses pemeliharaan induk ikan lele terdapat 2 jenis pakan yaitu pellet apung 781 sebagai pakan utama serta keong sawah sebagai pakan tambahan. Frekuensi pemberian pakan pellet untuk ikan lele 2 kali sehari yaitu pada pagi hari pukul 08.00 WIB dan sore hari pukul 16.00-17.00 WIB serta keong sawah diberikan dengan frekuensi pemberian pakan 2 kali dalam seminggu.

Proses pemijahan yang dilakukan menggunakan metode pemijahan secara buatan. Seleksi induk yang dilakukan dengan cara memilih induk yang memiliki tingkat kematangan gonad yang tinggi. Proses penyuntikan dilakukan dua kali dengan frekuensi jarak penyuntikan pertama dan kedua berjarak 5 jam. Proses pembuahan pada pemijahan secara buatan yaitu terdapat beberapa tahapan 
antara lain proses striping pada induk betina, proses pengambilan sel sperma pada induk jantan, dan proses pencampuran sel telur dan sperma. Penetasan telur dilakukan pada kolam penetasan dengan cara menebarkan telur yang sudah melalui proses pembuahan ke dalam kolam penetasan secara perlahan serta tutup kolam menggunakan paranet dan biarkan sampai telur menetas. Jangka waktu penetasan telur kurang lebih 2 hari.

Pemeliharaan benih berlangsung selama kurang lebih 1,5 bulan sampai benih mencapai ukuran yang dibutuhkan konsumen atau pasar. Pada proses pemeliharaan benih yang dilakukan melalui empat tingkatan pendederan. Pendederan 1 dilakukan selama 15 hari dari telur menetas, pendederan 2, 3, dan 4 dilakukan masing-masing selama 7 hari.

Pemberian pakan benih ikan lele pada kegiatan dempond menggunakan 3 jenis pakan yaitu telur puyuh, cacing sutera, dan pakan buatan berupa pellet. Pengelolaan kualitas air yang dilakukan yaitu mengamati nilai kualitas air menggunakan $\mathrm{pH}$ meter, alat TDS pengukur suhu dan secchidisk . Proses panen benih adalah tahapan setelah pemeliharaan dalam proses produksi sebelum melakukan penjualan. Tahapan panen benih dilakukan apabila ada pembeli yang memesan benih ikan lele. .

\section{Pemasaran Daring}

Pemasaran daring yang digunakan pada kegiatan penyuluhan yaitu aplikasi Facebook dan Whatsapp sebagai media untuk memasarkan benih ikan lele yang dihasilkan. Pendaftaran akun Facebook dilakukan dengan cara membuka situs www.Facebook.com pada peramban yang ada pada smartphone. Pengiklanan di sosial media yaitu menggunakan gambar sampel ikan yang akan dipasarkan dengan memberi keterangan spesifikasi ikan, lokasi serta nomor Whatsapp yang diunggah pada grupgrup perikanan Facebook. Transaksi jual beli dilakukan secara langsung yaitu pembeli mengambil benih di lokasi pelaku usaha atau dilakukan dengan cara pelaku usaha mengirim benih ke lokasi pembeli.

\section{Evaluasi Penyuluhan}

Analisis sistem penyuluhan berdasarkan program penyuluhan yang dilaksanakan yaitu penerapan metode pembenihan ikan lele secara buatan serta pemasaran daring melalui dempond. Menurut Mardikanto (1993) kegiatan evaluasi dilakukan terhadap 2 aspek, yaitu pengetahuan dan sikap (menggunakan skala Likert), dengan rumus sebagai berikut:

- AspekPengetahuan

Perubahan =Nilai Akhir-Nilai Awal 
- Aspek Sikap

Skala Likert $=\frac{\text { Total Nilai Skor }}{\text { Total Nilai Maksimum }} \times 100 \%$

Kegiatan evaluasi pada aspek keterampilan dilakukan dengan melakukan pengamatan dari segi kecepatan dan ketepatan pelaku usaha dalam melakukan kegiatan. Dari hasil evaluasi kemudian dihitung hasil perubahan yaitu dengan cara mencari selisih dari kegiatan evaluasi awal atau pre-test dan evaluasi akhir atau post-test sehingga diperoleh hasil perubahan.
HASIL DAN PEMBAHASAN

Hasil

Karakteristik Lokasi

Kecamatan Kalirejo memiliki luas $10.432 \mathrm{Ha}$ dengan pemanfaatan lahan antara lain seluas 816 ha $(7,82 \%)$ digunakan untuk pemukiman penduduk serta bangunan gedung, kemudian 1.023 ha $(9,80 \%)$ untuk pertanian terutama pada sektor tanaman padi, 8.065 ha $(77,31 \%)$ untuk perkebunan terutama pada sektor kelapa sawit, karet, singkong, dan kakao, 132 ha $(1,27 \%)$

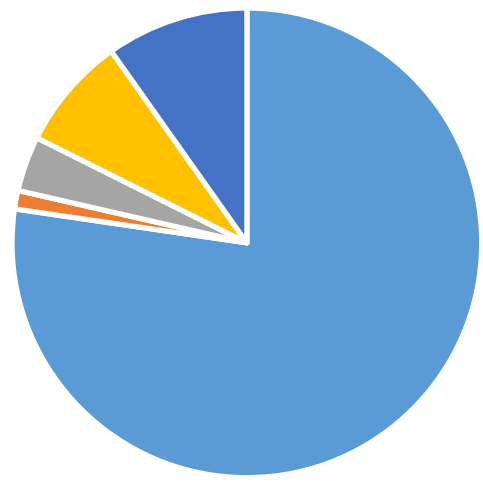

- Perkebunan

- Perikanan

- Lainnya

- Permukiman

- Pertanian

Gambar 1.Pemanfaatan Lahan di Kecamatan Kalirejo

Tabel1. Karakteristik Responden

\begin{tabular}{llcc}
\hline Karakteristik responden & \multicolumn{1}{c}{ Kategori } & Jumlah jiwa & Persentase (\%) \\
\hline \multirow{2}{*}{ Usia } & Kurang produktif $(<15)$ & 0 & 0 \\
& Produktif (15-64) & 12 & 100 \\
& Tidak produktif $(>64)$ & 0 & 0 \\
Pendidikan & Dasar (<SMP) & 7 & 58 \\
& Menengah (SMA) & 5 & 42 \\
\multirow{3}{*}{ Lama Usaha } & Tinggi (perguruan tinggi) & 0 & 0 \\
& Baru (<9) & 10 & 83 \\
& Sedang (10-19) & 2 & 17 \\
& Lama $(>20)$ & 0 & 0 \\
\hline
\end{tabular}


Tabel 2. Penggunaan Ovaprim

\begin{tabular}{|c|c|c|c|c|c|c|}
\hline \multirow[b]{2}{*}{ Kategori } & \multirow{2}{*}{$\begin{array}{c}\text { Berat } \\
\text { Awal } \\
\text { (gr) }\end{array}$} & \multicolumn{2}{|c|}{ Penyuntikan 1} & \multicolumn{2}{|c|}{ Penyuntikan 2} & \multirow{2}{*}{$\begin{array}{c}\text { Berat } \\
\text { Akhir } \\
\text { (gr) }\end{array}$} \\
\hline & & $\begin{array}{l}\text { Ovaprim } \\
\text { (ml) }\end{array}$ & $\mathrm{NaCl}(\mathrm{ml})$ & $\begin{array}{c}\text { Ovaprim } \\
\text { (ml) }\end{array}$ & $\mathrm{NaCl}(\mathrm{ml})$ & \\
\hline Betina & 940 & 0,3 & 0,7 & 0,3 & 0,7 & 800 \\
\hline Jantan 1 & 1.200 & 0,4 & 0,6 & 0,4 & 0,6 & 1.200 \\
\hline Jantan 2 & 980 & 0,3 & 0,7 & 0,3 & 0,7 & 980 \\
\hline
\end{tabular}

Tabel 3. Hasil Setiap Pendederan

\begin{tabular}{cccccc}
\hline Pendederan & Populasi & SR & $\begin{array}{c}\text { Berat rata- } \\
\text { rata }\end{array}$ & $\begin{array}{c}\text { Panjang } \\
\text { rata-rata }\end{array}$ & $\begin{array}{c}\text { Masa } \\
\text { pemeliharaan }\end{array}$ \\
\hline 1 & 77.829 & $78 \%$ & 0,14 & 1,6 & 15 \\
2 & 72.344 & $92,8 \%$ & 0,66 & 3,2 & 7 \\
3 & 68.676 & $95 \%$ & 0,95 & 4,9 & 7 \\
4 & 67.740 & 98,6 & 1,33 & 7,1 & 7 \\
\hline
\end{tabular}

Tabel 4. Jumlah Pakan per Hari pada Setiap Pendederan

\begin{tabular}{cccl}
\hline Uraian & Biomassa (gram) & Dosis pakan (\%) & \multicolumn{1}{c}{$\begin{array}{c}\text { Feeding Rate } \\
\text { (gram/hari) }\end{array}$} \\
\hline Pendederan 2 & 10.896 & 10 & $1.089,6$ \\
Pendederan 3 & 47.747 & 8 & $3.819,76$ \\
Pendederan 4 & 65.242 & 5 & $3.262,1$ \\
\hline
\end{tabular}

untuk kolam atau empang yang dimanfaatkan sebagai wadah usaha bidang perikanan, Serta 396 ha $(3,80 \%)$ termasuk pemanfaatan lahan lainnya yaitu pemakaman, lapangan umum dan akses jalan (Gambar 1).

\section{Karakteristik Responden}

Pengumpulan data profil sasaran bertujuan untuk menentukan materi penyuluhan yang akan digunakan sesuai dengan pendapat Yuniarti et al. (2020) yang mengatakan bahwa data-data profil kelompok perikanan, potensi sumber daya alam bermanfaat untuk menentukan jenis dan materi penyuluhan. Karakteristik Responden dapat dilihat pada Tabel1.

\section{Kegiatan Penyuluhan}

Dempond Pembenihan Ikan Lele Secara Buatan

$$
\text { Jumlah penggunaan hormon }
$$
ovaprim serta induk yang dipijahkan seperti pada Tabel 2. Hatching rate adalah tingkat persentase penetasan telur dalam sebuah proses pemijahan. Berikut adalah hasil perhitungan telur yang menetas sebesar $78,4 \%$. Hasil 


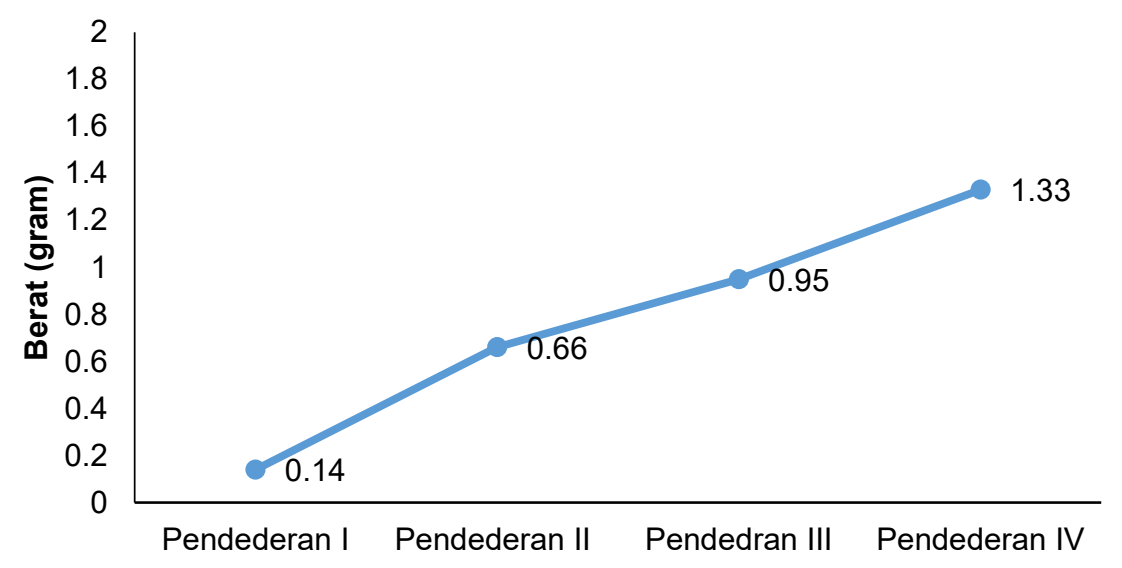

Gambar 2.Pertumbuhan Berat

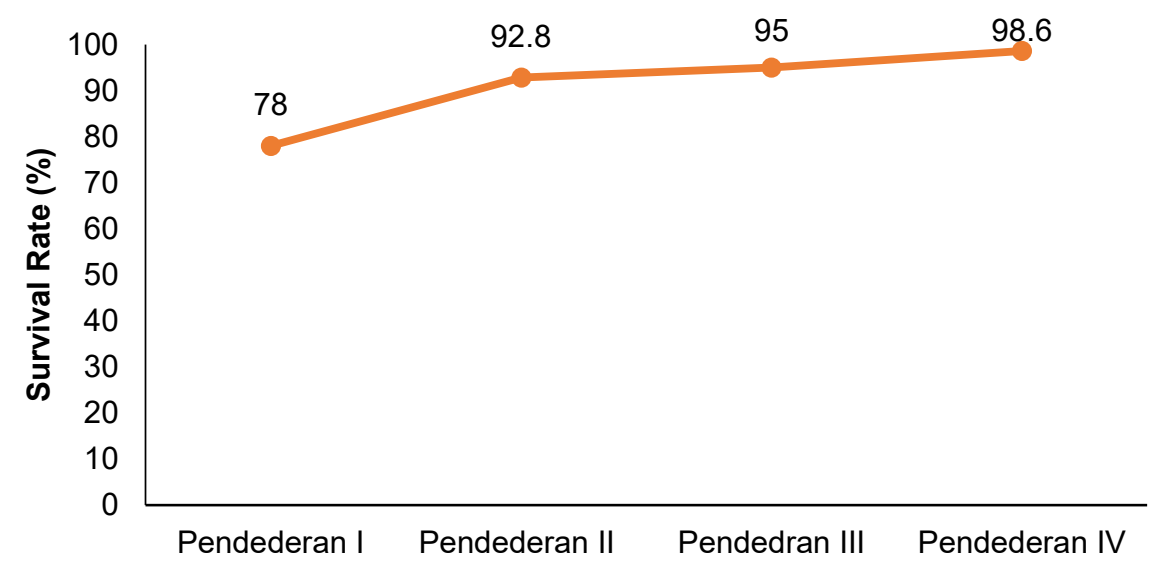

Gambar 3. Survival Rate

pemeliharaan pada setiap pendederan seperti pada Tabel 3.

$\mathrm{H}$ asil perhitungan pakan pellet pada setiap pendederan dapat dilihat di Tabel 4. Tingkat pertumbuhan berat, serta survival rate pada dempond pembenihan ikan lele dapat dilihat pada Gambar 2 dan 3.

Untuk pengukuran kualitas air pada kolam dempond dilakukan pagi dan sore selama 5 hari sekali dan pengamatan darurat apabila terjadi perubahan cuaca. Pengukuran kualitas air yang dilakukan yaitu suhu, $\mathrm{pH}$ dan kecerahan saja dikarenakan keterbatasan alat pada kelompok Taruna Mina Karya. Berdasarkan pengamatan yang dilakukan kisaran suhu pada kolam benih ikan lele yakni 25$30^{\circ} \mathrm{C}, \mathrm{pH}$ 6,7-8,2 dan Kecerahan $27-$ $34 \mathrm{~cm}$.

\section{Aspek Ekonomi Penyuluhan}

Analisis ekonomi dempond seperti pada Tabel 5, 6 dan 7 . 
Tabel 5. Biaya Pembenihan Ikan Lele

\begin{tabular}{|c|c|c|}
\hline No. & Jenis Biaya & Nilai (Rp.) \\
\hline 1 & Investasi & 13.460 .000 \\
\hline 2 & Penyusutan & 184.299 \\
\hline 3 & Tetap & 1.568 .598 \\
\hline 4 & Variabel & 2.188 .000 \\
\hline 5 & Total cost & 3.756 .598 \\
\hline
\end{tabular}

Tabel 6. Penerimaan Penjualan Benih

\begin{tabular}{llccc}
\hline No & Uraian & Jumlah (ekor) & Harga (Rp) & Penerimaan \\
\hline 1 & Penerimaan 1 & 30.000 & 90 & 2.700 .000 \\
2 & Penerimaan 2 & 35.000 & 120 & 4.200 .000 \\
\hline & Jumlah total & & & $\mathbf{6 . 9 0 0 . 0 0 0}$ \\
\hline
\end{tabular}

Tabel 7. Kelayakan Usaha Dempond Pembenihan Ikan Lele

\begin{tabular}{lll}
\hline No & Uraian & Hasil \\
\hline 1 & R/C Ratio & 1,83 \\
2 & Payback Period & 0,71 tahun \\
3 & BEP Rupiah & Rp. 3.504 .314 \\
4 & BEP Unit & 33.374 ekor \\
5 & Return of investment & $83 \%$ \\
\hline
\end{tabular}

\begin{tabular}{ccc|c|c|}
$\begin{array}{c}\text { Sangat tidak } \\
\text { setuju }\end{array}$ & Tidak setuju & Kurang setuju & Setuju & \multicolumn{2}{c}{ Sangat setuju } \\
\hline $0 \%$ & $25 \%$ & $50 \%$ & $75 \%$ & $90 \% \%$ \\
& & $48 \%$ & & $90 \% \%$
\end{tabular}

Gambar 4.Garis Kontinum Aspek Sikap

\section{Evaluasi Penyuluhan}

Hasil evaluasi penyuluhan yang diperoleh sasaran seperti pada Tabel 8,9 , serta Gambar 4.

\section{Pembahasan}

Karakteristik Lokasi

Kecamatan Kalirejo seluas 10.432 Ha yang terdiri dari wilayah pemukiman yang terdiri dari rumah penduduk serta 
Tabel 8. Tabel Aspek Pengetahuan

\begin{tabular}{llcccc}
\hline No & Sasaran & Pre test & Post test & Perubahan & $\begin{array}{c}\text { PersentasePeningkatan } \\
(\%)\end{array}$ \\
\hline 1 & Triyanto & 90 & 150 & 60 & 40 \\
2 & Timbul Aji & 80 & 150 & 70 & 46 \\
3 & Sarmudi & 100 & 150 & 50 & 33 \\
4 & Dodi Kurniawan & 80 & 150 & 70 & 46 \\
5 & PebriHermawan & 70 & 140 & 70 & 46 \\
6 & Ahmad dzulkifli & 70 & 150 & 80 & 53 \\
7 & Ahmad Nurrohman & 60 & 140 & 80 & 53 \\
8 & M Fatchurofik & 70 & 150 & 80 & 53 \\
9 & Sutarno & 90 & 140 & 50 & 33 \\
10 & UjangSujono & 80 & 150 & 70 & 46 \\
11 & Tomi Sugito & 60 & 80 & 20 & 13 \\
12 & Miswanto & 80 & 150 & 70 & 46 \\
\hline Rata-rata & $\mathbf{7 7 , 5}$ & $\mathbf{1 4 1 , 6}$ & $\mathbf{6 4}$ & $\mathbf{4 3}$ \\
\hline
\end{tabular}

Tabel 9. Indikator Aspek Keterampilan

\begin{tabular}{|c|c|c|c|c|c|c|c|}
\hline \multirow{2}{*}{ No } & \multirow{2}{*}{ Kegiatan } & \multicolumn{3}{|c|}{ Kecepatan } & \multicolumn{3}{|c|}{ Ketepatan } \\
\hline & & Terampil & $\begin{array}{l}\text { Cukup } \\
\text { Terampil }\end{array}$ & $\begin{array}{c}\text { Tidak } \\
\text { Terampil }\end{array}$ & Terampil & $\begin{array}{l}\text { Cukup } \\
\text { Terampil }\end{array}$ & $\begin{array}{c}\text { Tidak } \\
\text { Terampil }\end{array}$ \\
\hline 1. & $\begin{array}{l}\text { Mampu memilih dan } \\
\text { membedakan induk jantan dan } \\
\text { betina }\end{array}$ & $\begin{array}{c}5 \\
\text { ekor/menit }\end{array}$ & $\begin{array}{c}3 \\
\text { ekor/menit }\end{array}$ & $\begin{array}{c}1 \\
\text { ekor/menit }\end{array}$ & $100 \%$ & $50 \%$ & $0 \%$ \\
\hline 2. & $\begin{array}{l}\text { Mampu memilih induk matang } \\
\text { gonad }\end{array}$ & $\begin{array}{c}3 \\
\text { ekor/menit }\end{array}$ & $\begin{array}{c}2 \\
\text { ekor/menit }\end{array}$ & $\begin{array}{c}1 \\
\text { ekor/menit }\end{array}$ & $100 \%$ & $50 \%$ & $0 \%$ \\
\hline 3. & Mampu melakukan penyuntikan & $\begin{array}{l}2 \text { ekor/ } \\
10 \text { menit }\end{array}$ & $\begin{array}{l}1 \text { ekor/ } \\
10 \text { menit }\end{array}$ & $\begin{array}{l}0 \text { ekor/ } \\
10 \text { menit }\end{array}$ & $100 \%$ & $50 \%$ & $0 \%$ \\
\hline 4. & $\begin{array}{l}\text { Mampu melakukan striping pada } \\
\text { induk betina }\end{array}$ & $\begin{array}{l}2 \text { ekor/ } \\
20 \text { menit }\end{array}$ & $\begin{array}{l}1 \text { ekor/ } \\
20 \text { menit }\end{array}$ & $\begin{array}{l}0 \text { ekor/ } \\
\text { 20menit }\end{array}$ & $100 \%$ & $50 \%$ & $0 \%$ \\
\hline 5. & $\begin{array}{l}\text { Mampu melakukan pengambilan } \\
\text { sperma pada induk jantan }\end{array}$ & $\begin{array}{l}2 \text { ekor/ } \\
20 \text { menit }\end{array}$ & $\begin{array}{l}1 \text { ekor/ } \\
20 \text { menit }\end{array}$ & $\begin{array}{l}0 \text { ekorl } \\
20 \text { menit }\end{array}$ & $100 \%$ & $50 \%$ & $0 \%$ \\
\hline 6. & $\begin{array}{l}\text { Mampu melakukan proses } \\
\text { pencampuran sel telur dan } \\
\text { sperma }\end{array}$ & $\begin{array}{l}2 \text { ekor/ } \\
\text { 20menit }\end{array}$ & $\begin{array}{c}1 \text { ekor/ } \\
20 \text { menit }\end{array}$ & $\begin{array}{l}0 \text { ekor/ } \\
\text { 20menit }\end{array}$ & $100 \%$ & $50 \%$ & $0 \%$ \\
\hline 7. & $\begin{array}{l}\text { Mampu menggunakan media } \\
\text { Whatsapp dan Facebook }\end{array}$ & 1 menit & 3 menit & $\begin{array}{c}\text { Lebih dari } 5 \\
\text { menit }\end{array}$ & $5100 \%$ & $50 \%$ & $0 \%$ \\
\hline 8. & $\begin{array}{l}\text { Mampu membuat media } \\
\text { pemasaran daring (iklan) melalui } \\
\text { media internet (Whatsapp dan } \\
\text { Facebook) }\end{array}$ & menit & 5 menit & $\begin{array}{l}\text { Lebih dari } \\
10 \text { menit }\end{array}$ & $100 \%$ & $50 \%$ & $0 \%$ \\
\hline
\end{tabular}

bangunan gedung dengan pemanfaatan lahan dengan persentase $7,28 \%$. Persawahan yang dimanfaatkan penduduk sebagai tempat pertanian terutama pada sektor tanaman padi dengan pemanfaatan lahan $9,80 \%$. Perkebunan yang ada di Kecamatan Kalirejo mayoritas adalah perkebunan kelapa sawit, karet, sing- 
kong, dan kakao. Pemanfaatan lahan perkebunan $77,31 \%$. kolam atau empang dimanfaatkan sebagai wadah usaha bidang perikanan dengan pemanfaatan lahan $1,27 \%$. Serta yang termasuk pemanfaatan lahan lainnya adalah pemakaman, lapangan umum dan akses jalan dengan pemanfaatan lahan 3,80\% (BPS 2019).

\section{Karakteristik Responden}

Usia responden dikategorikan berdasarkan pada Undang-Undang No 13 tahun 2003 bahwa batas usia kerja yang berlaku di Indonesia adalah berumur 15 sampai 64 tahun. Karakteristik responden menunjukkan bahwa 12 responden termasuk kategori Usia Produktif yaitu pada kisaran 15 sampai 64 Tahun. Usia responden dapat berpengaruh pada tingkatan Adopsi Inovasi sesuai dengan pernyataan Amala et al (2013) yang menyatakan bahwa semakin muda pembudidaya maka lebih cepat melakukan Adopsi Inovasi.

Undang-Undang No 20 tahun 2003) mengategorikan tingkat pendidikan responden berdasarkan Jalur Pendidikan Formal yang terdiri atas Pendidikan Dasar, Pendidikan Menengah, dan Pendidikan Tinggi. Karakteristik responden pada tingkat pendidikan menunjukkan bahwa $58 \%$ responden termasuk kategori Pendidikan Dasar dan selebihnya adalah $42 \%$ kategori Pendidikan menengah. Menurut Amala et al. (2013) mengungkapkan bahwa mereka yang berpendidikan tinggi adalah yang relatif lebih cepat dalam melaksanakan adopsi, begitu pula sebaliknya mereka yang berpendidikan rendah agak sulit melaksanakan adopsi inovasi dengan cepat. Tumonglo, Purwanto, dan Mual (2017) berpendapat jika pendidikan yang dimiliki cukup, biasanya bersedia melakukan perubahan apabila ada jaminan bahwa perubahan tersebut akan membawa hasil yang lebih baik.

Manyamsari dan Mujiburrahmad (2014) menyatakan bahwa pengalaman usaha tani diklasifikasikan dalam kategori pengalaman baru adalah kurang dari 10 tahun, pengalaman sedang berkisar antara 10 sampai 20 tahun, dan pengalaman lama lebih dari 20 tahun. Karakteristik responden menunjukkan bahwa $83 \%$ responden termasuk kategori baru, dan $17 \%$ termasuk kategori sedang. Menurut pernyataan Amala et al. (2013) yang menyatakan bahwa pembudidaya yang sudah lama melakukan usahanya akan lebih mudah menerapkan inovasi dari pada pembudidaya pemula.

\section{Dempond Pembenihan Ikan Lele}

Percontohan usaha pada sasaran penyuluhan yang dilakukan yaitu pembenihan ikan lele secara buatan bertujuan untuk mengubah kebiasaan produksi 
sasaran agar dapat mengubah teknik produksi benih ikan lele yang lebih intensif. Proses dempond dilakukan mulai dari pemeliharaan induk, persiapan kolam, seleksi induk, pemijahan, pemeliharaan dan panen. pembenihan ikan lele secara buatan yang membedakan proses pemijahannya dilakukan dengan bantuan manusia di mana proses pemijahan dilakukan dengan cara menyuntikan hormon ovaprim pada induk jantan dan betina, selanjutnya induk jantan diambil kantong sperma dengan cara membuka bagian perut ikan sedangkan induk betina dilakukan proses striping untuk mengeluarkan telur yang ada pada perut induk betina. proses pembuahan dilakukan dengan cara mencampurkan cairan sperma dengan larutan $\mathrm{NaCl}$ dan telur ikan.

Ovaprim adalah campuran analog salmon Gonadotropihin Releasing Hormon (sGnRH-a) dan anti dopamine. Ovaprim adalah hormon yang berfungsi untuk merangsang dan memacu hormon gonadothropin pada tubuh ikan sehingga dapat mempercepat proses ovulasi dan pemijahan, yaitu pada proses pematangan gonad dan dapat memberikan daya rangsang yang lebih tinggi, menghasilkan telur dengan kualitas yang baik serta menghasilkan waktu laten yang relatif singkat juga dapat menekan angka mortalitas (Acharjee, Chaube, dan Joy 2017). Sedangkan menurut Satyani et al.
(2007) ovaprim adalah hormon yang berfungsi untuk merangsang dan memacu hormon gonadothropin pada tubuh ikan sehingga dapat mempercepat proses ovulasi dan pemijahan, yaitu pada proses pematangan gonad dan dapat memberikan daya rangsang yang lebih tinggi, menghasilkan telur dengan kualitas yang baik serta menghasilkan waktu laten yang relatif singkat juga dapat menekan angka mortalitas.

Penyuntikan pertama pada induk ikan menggunakan dosis yang sama dengan tahap penyuntikan kedua yaitu menggunakan dosis $0,3 \mathrm{ml}$ ovaprim dan tambahan lautan $\mathrm{NaCl} 0,7 \mathrm{ml}$. Hal ini sesuai dengan fungsi Ovaprim untuk merangsang hipofisa dalam melepaskan gonadotropin secara maksimal yang selanjutnya gonadotropin yang dilepas berperan dalam pematangan tahap akhir spermatozoa dalam gonad (Sukendi 2012).

Berat awal pada induk betina sebelum dilakukan proses striping dengan berat 940 gram, setelah proses striping dilakukan berat induk betina berkurang menjadi 800 gram, hal tersebut dapat diketahui bahwa berat gonad pada induk betina dengan berat total 140 gram. Untuk menghitung jumlah total telur (fekunditas) dapat diketahui dengan melakukan sampling pada telur. Berat sampling telur yang dilakukan yaitu 0,50 gram dengan jumlah telur 454 butir. 
Proses pembuahan terjadi kurang lebih selama 10 menit sampai sel telur tercampur semua dengan sel sperma sebelum melakukan penebaran ke kolam penetasan. Proses pembuahan pada sel telur sangat dipengaruhi oleh kualitas telur, kualitas sperma dan kecepatan sperma untuk bergerak spontan sehingga mampu masuk ke dalam lubang mikrofil pada sel telur. Selain itu pada kondisi pergerakan sperma aktif dan lincah, sperma mempunyai kemampuan dan energi untuk menembus lubang mikrofil telur, pergerakan spermatozoa yang semakin aktif menjadi salah satu faktor keberhasilan pembuahan(Hasan 2017).

Proses penetasan telur merupakan langkah terakhir pada masa inkubasi, yakni hasil dari beberapa proses sehingga embrio keluar dari cangkang (Redha, Raharjo, dan Hasan 2017). Selama penetasan telur kolam dialiri dengan debit air yang kecil, agar air terus berganti dan air yang kotor akibat pembusukan telur yang tidak terbuahi keluar melalui saluran outlet. Air mengalir tersebut juga digunakan untuk menjaga ketersediaan oksigen terlarut dalam kolam yang dapat mempercepat proses penetasan telur. Telur yang tidak menetas atau mati dibuang dengan cara disipon menggunakan selang kecil diameter $0,5 \mathrm{~cm}$. Setelah telur menetas, bak penetasan harus sering dikontrol atau diamati. Larva yang baru menetas berwarna hijau kehitaman seperti kecebong bergerak berenang di dasar kolam atau melayang.

Faktor internal yang mempengaruhi derajat penetasan telur adalah perkembangan embrio yang terlambat karena kualitas spermatozoa dan telur yang kurang baik. Sedangkan faktor eksternal yang berpengaruh terhadap penetasan telur adalah lingkungan yang di dalam terdapat temperatur air, oksigen terlarut, pH dan Amoniak (Hasan 2017)

Ernawati et al. (2021) menyatakan bahwa telur yang dihasilkan dari pemijahan buatan dapat menetas dalam waktu yang cukup singkat karena adanya penyuntikan hormon ovaprim yang dapat merangsang terjadinya proses ovulasi. Untuk menghitung persentase penetasan telur dilakukan pengambilan sampling pada telur yang dibuahi dan ditempelkan pada media jaring dengan ukuran $10 \mathrm{~cm} \times 10 \mathrm{~cm}$. Hatching rate adalah tingkat persentase penetasan telur dalam sebuah proses pemijahan. Berikut adalah hasil perhitungan telur yang menetas. Hasil dempond pembenihan ikan lele secara buatan menghasilkan tingkat penetasan telur mencapai $78,4 \%$ hal tersebut menyimpulkan bahwa tingkat penetasan yang dilakukan mencapai nilai $70-80 \%$ persentase penetasan telur yang baik berdasarkan pernyataan Iswanto et al. (2015) derajat 
penetasan telur ikan lele strain mutiara berkisar $70-80 \%$.

Pemeliharaan benih pada kolam dempond dilakukan melalui 4 tahapan pendederan yaitu berdasarkan umur benih dan permintaan pasar. Dalam pemeliharaan benih melakukan grading untuk memisahkan benih berdasarkan ukuran dan menghitung tingkat Long Growth, Weight Growth, Survival Rate, serta populasi. Pendederan I dilakukan selama 15 hari mulai dari penetasan sampai umur 15 hari. Pendederan II dilakukan selama 7 hari mulai dari umur 16-22 hari. Pendederan III dilakukan selama 7 hari mulai dari umur 23-29 hari. Pendederan IV merupakan pendederan terakhir yang dilakukan pada dempond pembenihan ikan lele secara buatan dilakukan selama 7 hari sampai panen benih, mulai dari umur 30-36. Hasil pendederan IV merupakan hasil panen benih.

Data hasil dempond menunjukkan tingkat kehidupan yang paling rendah terjadi pada pendederan 1 dengan persentase survival rate hanya mencapai $78 \%$. Hal tersebut diakibatkan oleh cuaca yang berubah-ubah dari panas ke hujan. Perubahan cuaca sewaktu-waktu dapat mengakibatkan kurang standarnya kualitas air dan dapat mengakibatkan kematian pada benih ikan, karena daya tahan tubuh benih pada fase pendederan
1 masih kurang dibandingkan benih pada fase pendederan 2 sampai 4 .

Menurut Lukito dan Prayugo (2007), pakan buatan pabrik dalam bentuk pellet sangat digemari ikan lele, tetapi harga pellet relatif mahal sehingga penggunaannya harus diperhitungkan agar tidak rugi. Ikan lele (Clariassp.) dapat memakan segala macam makanan, tetapi pada dasarnya bersifat karnivora (pemakan daging), maka pertumbuhannya akan lebih pesat bila diberi pakan yang mengandung protein hewani dari pada diberi pakan dari bahan nabati. Benih lele berumur 10 hari pemberian pakan mulai menggunakan pellet. Frekuensi pemberian pakan 5 kali sehari yakni pukul 06.00, 12:00, 17.00, 20.00 dan 24:00 WIB secara ad satiation. Pemberian pakan berdasarkan ukuran benih dan ukuran pakan. Untuk pakan PF-0 diberikan pada benih ukuran $<2 \mathrm{~cm}$, dan PF-500 untuk benih ukuran $>2 \mathrm{~cm}$.

Suhu atau temperatur merupakan salah satu faktor penentu kehidupan ikan. Hasil pengukuran suhu pada kolam dempond yakni berkisar $25^{\circ}-30^{\circ} \mathrm{C}$. Amri (2002) dalam Koniyo (2020), menyatakan bahwa kisaran suhu yang baik bagi kehidupan ikan antara $25-30^{\circ} \mathrm{C}$ sementara itu, jika suhu air berada di bawah $14^{\circ} \mathrm{C}$ ikan akan mengalami kematian. Jika suhu air turun hingga di bawah $25^{\circ} \mathrm{C}$ daya cerna ikan terhadap makanan yang dikonsumsi berkurang. Parameter suhu 
air kolam masuk pada kategori baik sesuai dengan pendapat Iswanto et al. (2015) bahwa kualitas air yang dianggap baik untuk kehidupan lele mutiara adalah suhu yang berkisar antara $15^{\circ}-35^{\circ} \mathrm{C}$, dengan kandungan oksigen terlarut harus melebihi $0 \mathrm{mg} / \mathrm{L}$, $\mathrm{pH} 5-10$, nitrit kurang dari $0,3 \mathrm{mg} / \mathrm{L}$ dan $\mathrm{NH} 3<3 \mathrm{mg} / \mathrm{L}$.

\section{Pemasaran dan Aspek Ekonomi}

Promosi melalui media Facebook kelompok Taruna Mina Karya sudah melakukan pemasaran di luar Provinsi Lampung antara lain di wilayah Bogor dan Tangerang. Pengiriman benih kepada Bapak Arif sebagai konsumen wilayah Bogor sudah dilakukan tiga kali, sedangkan pengiriman kepada Bapak Adam konsumen wilayah Tangerang sudah baru dilakukan satu kali. Promosi melalui grup-grup tentang perikanan yang ada di Facebook bermaksud untuk dapat menjangkau konsumen dan pasar lebih jauh. Hal tersebut terlihat pada anggota grup perikanan yang berasal dari beberapa tempat diindonesia. Tahapan kegiatan pada proses pemasaran diawali dengan pembuatan akun Facebook dengan nama "Waroeng Iwak" yang merupakan wadah pemasaran serta pengiklanan bagi kelompok Taruna Mina Karya. Iklan di sosial media menggunakan gambar sampel ikan yang akan dipasarkan dengan memberi keterangan spesifikasi ikan, lokasi serta nomor Whatsapp agar mudah untuk berkomunikasi dengan calon pembeli.

Sesuai dengan pendapat Muttaqin (2012) Facebook marketing adalah melakukan aktivitas marketing menggunakan semua fasilitas yang disediakan oleh Facebook dengan tujuan meningkatkan penjualan (sales) dan menjalin komunikasi yang lebih langgeng dengan pelanggan (customer relationship). Sedangkan menurut Wandanaya (2012), bahwa kegiatan pemasaran Internet umumnya meliputi atau berkisar pada hal-hal yang berhubungan dengan pembuatan produk periklanan, pencarian prospek atau pembeli dan penulisan

Transaksi jual beli dilakukan secara langsung oleh pembeli yang mengambil benih di lokasi pelaku usaha atau dilakukan dengan cara pelaku usaha mengirim benih ke lokasi pembeli. Proses transaksi dilakukan sesuai dengan kesepakatan antara pembeli dan penjual melalui komunikasi Whatsapp ataupun Facebook. Tujuan utama dalam komunikasi pemasaran adalah memengaruhi. Komunikasi dimaksud untuk menginformasikan, mendidik, menciptakan kesadaran, minat, kebutuhan atau hasrat atas sebuah produk. Komunikasi dilakukan oleh dua lembaga pemasaran yaitu produsen (pelaku usaha) dan konsumen (pembeli). Dalam proses komunikasi melalui media sosial maka terjadilah proses tawar menawar antara 
penjual dan pembeli. Pada saat kegiatan dempond berlangsung, sudah banyak pembeli yang melakukan komunikasi namun hanya beberapa pembeli yang sampai pada tahap transaksi pembelian benih.

Hasil perhitungan analisis usaha dempond pembenihan ikan lele secara buatan berdasarkan tabel kelayakan usaha, usaha dempond pembenihan ikan lele secara buatan masuk pada kategori layak untuk dikembangkan dilihat dari nilai keuntungan yang diperoleh sebesar Rp. 3.143.402/siklus, serta nilai hasil perhitungan kelayakan usaha lainnya seperti R/C Ratio 1,83, Payback Period 0,71, BEP Harga Rp 3.504.314, BEP Unit 33.374 ekor, dan ROI 83\%. Hasil analisis ekonomi pada dempond pembenihan ikan lele secara buatan yang hanya menggunakan satu induk betina dapat menghasilkan 65.000 ekor benih, memperoleh keuntungan sebesar Rp.3.143.402 sedangkan pembenihan ikan lele secara alami yang telah dilakukan sebelumnya oleh sasaran menggunakan dua induk betina hanya dapat menghasilkan 85.000 ekor benih dan memperoleh keuntungan Rp. 3.510.342.

Hasil pemasaran selama kegiatan dempond, pemasaran melalui media internet sudah jelas terbukti dapat menjangkau pasar lebih luas dan harga lebih tinggi sedangkan pemasaran offline hanya mengandalkan tengkulak benih di daerah setempat, harga benih tergolong sangat rendah di mana ukuran 5-7 cm hanya dibeli dengan harga Rp.90. Dengan proses pemasaran daring pelaku usaha mampu bersaing harga di luar daerah tentunya harga yang ditetapkan lebih tinggi dengan harga diambil oleh pengepul di Kecamatan Kalirejo di mana ukuran 5-7 cm berkisar antara Rp.150 - Rp.170. pemasaran daring lebih efektif diterapkan untuk dapat meningkatkan keuntungan dalam proses produksi.

Proses pemasaran yang terjadi di lapangan rata-rata pembeli tidak mau untuk membayar $50 \%$ dari jumlah benih yang dipesan melainkan prinsip pembeli akan membayar benih apabila benih telah sampai, berdasarkan pernyataan tersebut merupakan suatu masalah serta kendala dalam menjangkau pasar, di mana pelaku usaha tidak mau untuk melakukan pengiriman benih ke lokasi pembeli karena risiko perjalanan serta kerugian yang besar apabila pembeli hilang kontak pada saat proses perjalanan pengiriman benih. Maka dari itu penulis mencoba untuk tetap melakukan pengiriman benih ke lokasi pembeli mengikuti permintaan transaksi pembeli.

\section{Evaluasi Kegiatan Penyuluhan}

Analisis evaluasi penyuluhan berdasarkan program penyuluhan yang 
dilakukan yaitu penerapan metode pembenihan ikan lele secara buatan serta pemasaran daring melalui dempond. Keberhasilan pelaksanaan percontohan usaha (dempond) dinilai dengan adanya perubahan pengetahuan, keterampilan, dan sikap dari sasaran. Penilaian awal (pre test) pada sasaran dilakukan sebelum melakukan proses dempond atau pada saat sebelum melakukan penyampaian materi penyuluhan dengan melakukan penilaian menggunakan alat bantu kuesioner. Hal ini dilakukan untuk mengetahui sejauh mana pengetahuan, sikap dan keterampilan awal pelaku usaha dalam proses pembenihan ikan lele dan proses pemasarannya.

Hasil evaluasi aspek pengetahuan berdasarkan dengan data hasil di lapangan, pada kuesioner pre-test tingkat pengetahuan rata-rata sasaran hanya 77,5 setelah kegiatan penyuluhan ratarata persentase tingkat pengetahuan sasaran mengalami perubahan peningkatan sebesar $43 \%$. Berdasarkan gambar garis kontinum di atas dapat dilihat bahwa terjadi peningkatan aspek sikap dalam kegiatan dempond pembenihan ikan lele secara buatan dan pemasaran daring, hal tersebut dapat diketahui bahwa tingkat persetujuan dilihat dari nilai mutlak pada saat dilakukan pre-test berada pada kategori tidak setuju dengan nilai mutlak $48 \%$ yang didapat dari jumlah jawaban pre-test, sedangkan saat dilakukan post-test terjadi perubahan menjadi kategori setuju dengan nilai mutlak $90 \%$ yang didapat dari jumlah jawaban post-test. Dilihat dari hasil tersebut maka dapat disimpulkan bahwa responden yang awalnya pada tidak setuju kemudian berubah menjadi setuju setelah diberikan penyuluhan berupa penyampaian materi dempond.

Hasil rekapitulasi dari aspek keterampilan yang telah dilakukan dengan delapan kegiatan, kategori responden diperoleh dari hasil nilai terbanyak pada tingkat kecepatan dan ketepatan. Evaluasi awal mengenai dempond pembenihan ikan lele secara buatan dan pemasaran daring pada aspek keterampilan hasilnya tidak terampil, setelah proses kegiatan penyuluhan dilakukan hasil kegiatan dempond pembenihan ikan lele secara buatan dan pemasaran daring pada 12 responden, yang terampil satu responden, cukup terampil tujuh responden dan tidak terampil empat responden. Hal tersebut memperlihatkan bahwa kegiatan penyuluhan memberikan dampak yang sangat baik kepada responden yaitu memberikan perubahan keterampilan yang sebelumnya tidak terampil setelah penyuluhan menjadi cukup terampil dengan adanya kegiatan pelatihan penyuluhan pembenihan ikan lele secara buatan dan pemasaran daring yang disampaikan. 


\section{SIMPULAN}

Kegiatan penyuluhan yang disampaikan menggunakan metode dempond (percontohan usaha) pemijahan secara buatan sangat efektif diterapkan untuk meningkatkan hasil produksi benih. Kegiatan pemasaran melalui media internet yang dilakukan telah berhasil menjangkau wilayah pasar yang lebih luas, antara lain wilayah Tangerang dan Bogor. Pemasaran melalui media internet sangat efektif diterapkan serta dapat meningkatkan harga jual dan perekonomian pelaku usaha. Aspek pengetahuan responden mengalami persentase peningkatan rata-rata $43 \%$, aspek sikap mengalami perubahan dari kategori tidak setuju menjadi kategori setuju dengan nilai mutlak $90 \%$. Sedangkan pada aspek keterampilan sasaran berubah dari kategori tidak terampil rata-rata menjadi cukup terampil.

\section{PERSANTUNAN}

Ucapan terima kasih disampaikan kepada Koordinator Penyuluh Kabupaten Lampung Tengah, pemangku kepentingan terkait, serta seluruh anggota kelompok Taruna Mina Karya Kecamatan Kalirejo Provinsi Lampung.

\section{DAFTAR PUSTAKA}

Acharjee, A., R. Chaube, dan K. P. Joy. 2017. "Ovaprim, a commercial spawning inducer, stimulates gonadotropin subunit gene transcriptional activity: A study correlated with plasma steroid profile, ovulation and fertilization in the catfish Heteropneustes fossilis." General and Comparative Endocrinology 251:66-73. doi: 10.1016/j.ygcen.2016.10.001.

Amala, Tasnim, Diana Chalil, dan Luhut Sihombing. 2013. "Faktor Faktor yang Berhubungan Dengan Adopsi Petani Terhadap Sistem Pertanian Padi Organik." Journal on Social Economics of Agriculture and Agribusiness 2(11):1-12.

BPS. 2019. Kecamatan Kalirejo Dalam Angka 2019. Lampung Tengah (ID): Badan Pusat Statistik Kabupaten Lampung Tengah.

Ernawati, Ernawati, Mohammad Sayuti, Kadarusman Kadarusman, Intanurfehmi B. Hismayasari, Iman Supriatna, dan Agung Setia Abadi. 2021. "Pendampingan Masyarakat di Kampung Salak, Kota Sorong: Pelatihan Teknik Pembenihan Ikan Lele Secara Buatan." Yumary: Jurnal Pengabdian Kepada Masyarakat 1(4):173-81. doi: 10.35912/yumary.v1i4.195.

Hasan, Uswatul. 2017. "Daya Tetas Telur 
dan Sintasan Larva dari Hasil Penambahan Madu pada Bahan Pengencer Sperma Ikan Lele Sangkuriang (Clarias sp).”." Jurnal Warta Dharmawangsa 54:1-18. doi: 10.46576/wdw.v0i54.285.

Iswanto, Bambang, Rommy Suprapto, Huria Marnis, dan Imron Imron. 2015. "Karakteristik Morfologis dan Genetis Ikan Lele Afrika (Clarias gariepinus Burchell, 1822) Strain Mutiara." Jurnal Riset Akuakultur 10(3):325. doi:

10.15578/jra.10.3.2015.325-334.

Koniyo, Yuniarti. 2020. "Analisis Kualitas

Air pada Lokasi Budidaya Ikan Air

Tawar di Kecamatan Suwawa Tengah." Jurnal Technopreneur (JTech) 8(1):52-58. doi: 10.30869/jtech.v8i1.527.

Lukito, Agung, dan Surip Prayugo. 2007.

Panduan Lengkap Lobster Air

Tawar. Jakarta (ID): PT Penebar Swadaya.

Manyamsari, Ira, dan Mujiburrahmad Mujiburrahmad. 2014. "Karakteristik Petani Dan Hubungannya Dengan Kompetensi Petani Lahan Sempit (Kasus: Di Desa Sinar Sari Kecamatan Dramaga Kab. Bogor Jawa Barat)." Jurnal Agrisep Unsyiah 15(2):58-74. doi: 10.24815/agrisep.v15i2.2099.

Mardikanto, Totok. 1993. Penyuluhan

Pembangunan Pertanian. Surakarta
(ID): Sebelas Maret University Press.

Muttaqin, Zainal. 2012. "Facebook Marketing dalam Komunikasi Pemasaran Modern." Teknologi 1(2). doi: 10.26594/teknologi.v1i2.63.

Prastiyo, B. 2021. Identifikasi Potensi Usaha Perikanan serta Kegiatan Penyuluhan di Kecamatan Kalirejo, Provinsi Lampung. Bogor (ID).

Redha, Akhmad Rasyid, Eka Indah Raharjo, dan Hastiadi Hasan. 2017. "Pengaruh Suhu yang Berbeda Terhadap Perkembangan Embrio dan Daya Tetas Telur Ikan Kelabau (Osteochilus melanopleura)." Jurnal Ruaya : Jurnal Penelitian dan Kajian Ilmu Perikanan dan Kelautan 4(2). doi: 10.29406/rya.v4i2.481.

Satyani, Darti, Jacques Slembrouck, Siti Subandiyah, dan Marc Legendre. 2007. "Peningkatan Teknik Pembenihan Buatan Ikan Hias Botia, Chromobotia Macracanthus (Bleeker)." Jurnal Riset Akuakultur 2(2):135-42. doi:

10.15578/jra.2.2.2007.135-142.

Sukendi. 2012. Teknologi Pembenihan Dan Budidaya Ikan Kapiek. Riau (ID): Pusat Pegembangan Pendidikan Universitas Riau.

Tumonglo, Suryanti, Benang Purwanto, dan Carolina Diana Mual. 2017. "Evaluasi Penyuluhan Pemanfaatan 
Daun Sirih Sebagai Pestisida Nabati

Dalam Mengendalikan Hama Ulat

Tritip (Plutella Xylostella) Pada

Tanaman Sawi Di Kampung

Wamesa Distrik Manokwari Selatan

Kabupaten Manokwari." Jurnal Triton 8(2):46-57.

Undang-Undang No 13. 2003. Tentang

Tenaga Kerja.

Undang-Undang No 20. 2003. Tentang

Sistem Pendidikan Nasional.

Wandanaya, Anita B. 2012. "Pengaruh
Pemasaran Online terhadap

Keputusan Pembelian Produk." CCIT Journal 5(2):174-85. doi: 10.33050/ccit.v5i2.149.

Yuniarti, Tatty, Jasmine Adinda Putri, Ita Junita Puspa Dewi, dan Ani Leilani. 2020. "Adoption of Fisheries Diversification Innovation in Poklahsar in Cigasong Sub-District, Majalengka District." Jurnal Penyuluhan 16(2):289-302. doi: $10.25015 / 16202030683$. 